\title{
Geological Models of Platinum Group Elements (PGE) Depletion in Metamorphosed Ultramafic Rocks of the Nyong Series, Southeast Cameroon
}

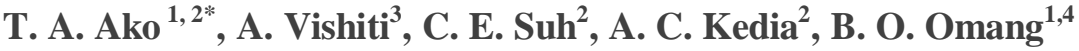

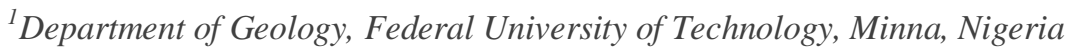 \\ ${ }^{2}$ Department of Geology, University of Buea, Cameroon \\ ${ }^{3}$ Department of Mining and Extractive Metallurgy, Institute of Science, Engineering and Technology, Cameroon \\ Christian University, Bali, Cameroon \\ ${ }^{4}$ Department of Mineral and Petroleum Resources Engineering, Federal Polytechnic, Auchi, Nigeria
}

*Corresponding Author: T. A. Ako, Department of Geology, Federal University of Technology, Minna, Nigeria

\begin{abstract}
Meta-ultramafic rocks in the Paleoproterozoic Nyong Series (SE Cameroon) which occur as intrusions within the metasedimentary and meta-igneous units have been studied. The aim was to study the concentration of platinum group elements (PGEs) within the layered sequence and suggests models of their depletion relevant to the rocks. Twenty-seven samples of the ultramafic rocks were collected from the different layers of the sequence and analysed for their $\mathrm{Ni}, \mathrm{Cu}, \mathrm{Au}$ and PGE contents. $\mathrm{Ni}, \mathrm{Cu}, \mathrm{Au}, \mathrm{Pt}$ and Pd were analysed by ICP-MS while Ir, Os, Rh and Ru were analysed by INAA. Results of the analyses show that the concentrations of $\mathrm{Cu}, \mathrm{Au}, P G E$ and $\Sigma P G E$ are very low throughout the cliff face while Ni concentrations are high and variable. The effect of alteration of the rocks has resulted in the low PGE concentration due to remobilization. It is also suggested that the rocks are PGE-depleted due to low degree of partial melting or depleted mantle source and various models have been used to explain this depletion as related to the Nyong Series.
\end{abstract}

Keywords: instrumental neutron activation analysis, ultramafic rocks, PGE depletion model, Poyi Poshi, Nyong Series

\section{INTRODUCTION}

Platinum group elements (PGEs) belong to Group 8, periods V and VI of the transition metals and they include platinum (Pt), palladium (Pd), rhodium (Rh), Iridium (Ir), Osmium (Os) and ruthenium $(\mathrm{Ru})$. These six chemically similar elements comprise the light platinum elements $(\mathrm{Ru}, \mathrm{Rh}, \mathrm{Pd})$ and the heavy platinum elements (Os, Ir and Pt). Together with gold and silver, the PGEs are precious metals and occur rarely in the earth's crust. The average crustal abundance of Pt and Pd is $5 \mathrm{ppb}$ while $\mathrm{Rh}, \mathrm{Ru}$ and $\mathrm{Ir}$ are even rarer with approximately $1 \mathrm{ppb}$. Due to their similarity in physical and chemical characteristics, the PGEs often occur naturally together and can be mined together as coproducts with Pt normally providing the reason behind PGE production levels (Polinares Consortium, 2012). These elements are strongly siderophile and chalcophile (e.g. Brain, 2011; Ranvide et al., 2015) and have similar geochemical behaviors during magmatic processes. Traditionally, the PGEs can be subdivided into two groups, the compatible IPGEs which include Os, Ir and Ru and the incompatible PPGEs which are made up of Rh, Pd and Pt (Qing et al., 2012). It has been suggested that the IPGEs are refractory and tend to be retained in the mantle peridotite during partial melting (Brain, 2011; Evans et al., 2012; Barnes et al., 2011). Most economic PGE deposits belong to a continuum of Ni-Cu-PGE sulfide mineralization styles from those that tend to be sulfide-poor and mined mainly for their PGE contents, to those that are sulfide-rich and are mined mainly for their Ni$\mathrm{Cu}$ contents (Keays and Lightfoot, 2002). PGE mineralization in magmatic deposits is formed in three different ways (Holwell and McDonald, 2010). These include (1) fractional separation of PGEs during magma crystallization, (2) PGE concentration in the oxide-ore phase forming segregations, and (3) PGE extraction from magma into immiscible sulfide liquids. 
A larger part of the Cameroon basement is made up of ancient crystalline rocks which have been deformed multiple times and re-metamorphosed during various tectonic events resulting in the development of structures which have implications on mineralization. In the Nyong Series these structures are thought to have controlled the emplacement of ultramafic bodies which are potential PGE host rocks. Studying ultramafic rocks across the globe throws more light on mechanisms of PGEs enrichment and this will enhance exploration strategies. This is regardless if the ultramafics are mineralised or barren. This work therefore studies ultramafic rocks and proposes models of PGE depletion in rocks relevant to the Nyong Series.

\section{REgional GeOlogical SETTING}

The Nyong Series is part of the West Central African Belt (WCAB) of Eburnean age (2400 - 1800 Ma) which has been differentiated into cratons and mobile zones in central African (Bessoles and Lassere, 1980). It corresponds to the WCAB known in Cameroon, Gabon, Central African Republic, Republic of Congo, Democratic Republic of Congo and Angola and extends through the Transamazonian Belt in Brazil (Lerouge et al., 2006; Owona, 2011). The Nyong Series occupies the NW border of the Ntem complex that was remelted during the collision of the São Francisco and Congo cratons (Ledru et al., 1994) is dominated by metasedimentary rocks. It comprises of various rocks (including biotite gneisses and amphibolites with or without biotite gneisses) quartzites associated with BIFs and pyroxene-garnet-bearing amphibolites (Lerouge et al., 2006). The unit which is the NW corner of the Congo craton is a metasedimentary and metaplutonic rock unit that underwent a high grade tectono-metamorphic event at $\sim 2050 \mathrm{Ma}$ associated with charnockite formation (Lerouge et al., 2006) and is bordered by the Ntem unit at the SE part, the Pan-African gneiss formations at the north and NE parts and by the Quaternary sedimentary formations at the NW part (Figure 1) (Ebah Abeng et al., 2012). It is a high-grade gneiss unit, which was initially defined as a Neoproterozoic, or palaeoproterozoic- reactivated NW corner of the Archaean Congo craton (Lasserre and Soba, 1976; Feybesse et al., 1986; Lerouge et al., 2006). The unit is made up of a greenstone belt (pyroxenites, amphibole-pyroxenites, peridotites, talcschists, amphibolites and banded iron formations), foliated series (TTG and gneiss), and magmatic rocks (augen metadiorites, granodiorites and syenites) (Shang et al., 2010; Lerouge et al., 2006; Owona et al., 2011).

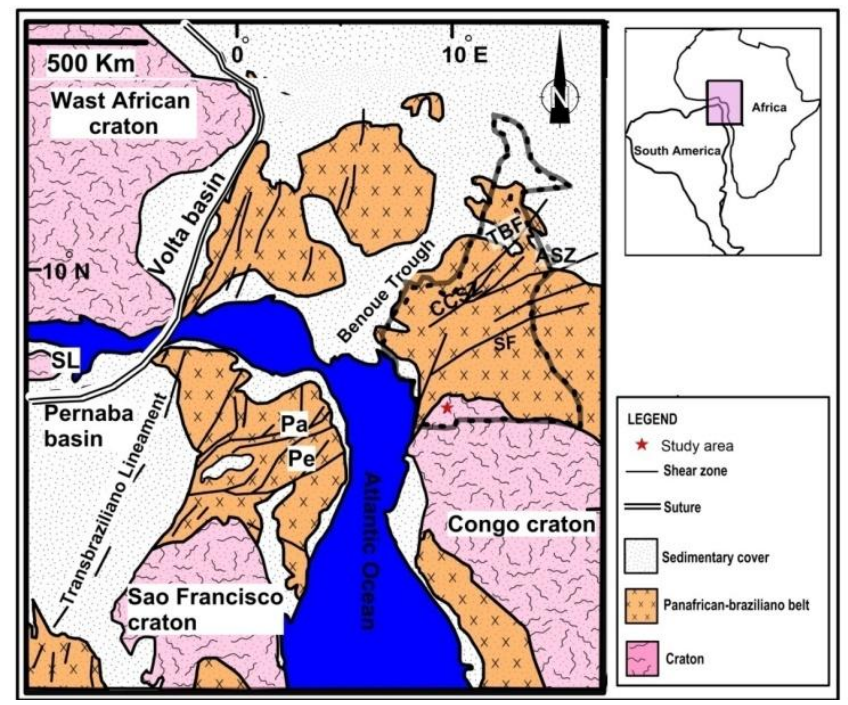

Figure1. Geological map of the pre-drift Gondwana showing the Congo craton in Cameroon and the northern part of São Francisco craton of Brazil (modified after Ebah Abeng et al., 2012)

This large belt resulted from the collision between the Congo and São Francisco cratons. Most of the WCAB is characterized by tectonic reworking of Archean crust with little addition of juvenile material, particularly in the southern part of the belt (Toteu et al., 1994a). However, this dominant recycling character is diminished northward with the appearance of $\sim 2.1 \mathrm{Ga}$ juvenile met asedimentary and meta-plutonic rocks intensively reworked and dismembered in the Pan-African belt north of the Congo craton (Pénaye et al., 2004). The Nyong Series (coined as Nyong Group, e.g. Lerouge et al., 2006; Owona et al., 2011; Owona et al., 2013) in the northwestern corner of the Congo craton in Cameroon is a-well-preserved granulitic unit of the WCAB resting as an Eburnean nappe on the Congo craton (Feybesse et al., 1986; Toteu et al., 1994b). 


\section{Materials ANd Methods}

The field study consisted of systematic mapping and sampling of lithological units of the selected area within the Nyong Series where ultramafic rocks were found. A total of twenty seven samples were collected during the field work and later used for analyses. All the samples were crushed using a jaw crusher with steel plates. The crushed samples were pulverized in a ball mill made up of $99.8 \% \mathrm{Al}_{2} \mathrm{O}_{3}$ at the ACME Analytical Laboratory, Vancouver, Canada. A two-step loss on ignition (LOI) was done in which powders were first heated at $105^{\circ} \mathrm{C}$ in the presence of nitrogen to drive off adsorbed water and then ignited at $1000^{\circ} \mathrm{C}$ in the presence of oxygen to drive off the remaining volatile components.

Nickel $(\mathrm{Ni})$ and copper $(\mathrm{Cu})$ were analysed by ICP-MS while gold $(\mathrm{Au})$, platinum $(\mathrm{Pt})$ and palladium (Pd) were analysed by Ni sulphide fire assay method (code 3B-MS). A $25 \mathrm{~g}$ aliquot of each sample was fused at $1000^{\circ} \mathrm{C}$ with a suitable amount of flux for the sample matrix with nickel oxide and sulphur added as a carrier. The resulting nickel sulphide button was extracted, ground and partially dissolved in $1 \mathrm{MHCl}$ under a high enough $\mathrm{f}_{\mathrm{H} 2 \mathrm{~S}}$ to ensure that the precious metals remain insoluble. The resulting insoluble residues containing the precious metals was dissolved in aqua regia and analysed by ICP-MS. Au, Pt and Pd had detection limits of 2, 3 and $2 \mathrm{ppb}$ respectively.

The remaining PGEs (Ir, Os, Rh and Ru) were determined by nickel-sulphide fire assay followed by Te co-precipitation (code NAA-2). The sample solutions were melted with sodium carbonate and sodium tetraborate in the presence of nickel sulfide melt. After the quenching of each sample, a bead of $\mathrm{NiS}$ was broken out of the crucible and digested by concentrated $\mathrm{HCl}$ in Telfon vessels using concentrated $\mathrm{HCl}$ acid. Tellurium co-precipitation was used to ensure that the insoluble residue to acid digestion retained all Au-PGE. Solutions were filtered in a vacuum after which the precipitate was redissovled in aqua regia and deionized water. The resulting solutions were analysed by instrumental neutron activation analysis (INAA). Details of this method are contained in Savard et al. (2010). The detection limits for Ir, Os, Rh and Ru was 1, 10, 5 and $50 \mathrm{ppb}$ respectively. All the analyses were done at Acme Analytical Laboratory, Vancouver, Canada. The accuracy of the analytical results was verified through the analysis of matrix-matched reference materials, and any potential contamination during sample preparation and analysis was monitored via suitable black materials. All analytical data presented in this work passed through quality control tests to ascertain the reliability of the results.

\section{RESULTS AND DisCUSSIONS}

\subsection{Field Characteristics of the Ultramafic Rocks}

The study area is made up of two distinct rock units. These units are the metasedimentary unit which is represented by the talc-tremolite schists and these rocks occur as floats of blocks with fine to medium-grained texture and a meta-igneous unit which is made up of amphibole-pyroxene gneiss, amphibole-garnet gneiss and biotite-garnet gneiss. These units have been intruded by ultramafic rocks which were sampled for this study. The ultramafic unit investigated is a layered sequence exposed on a cliff face and details of the geology and petrography are contained in Ako et al., 2015 and depicted in Figure 2.

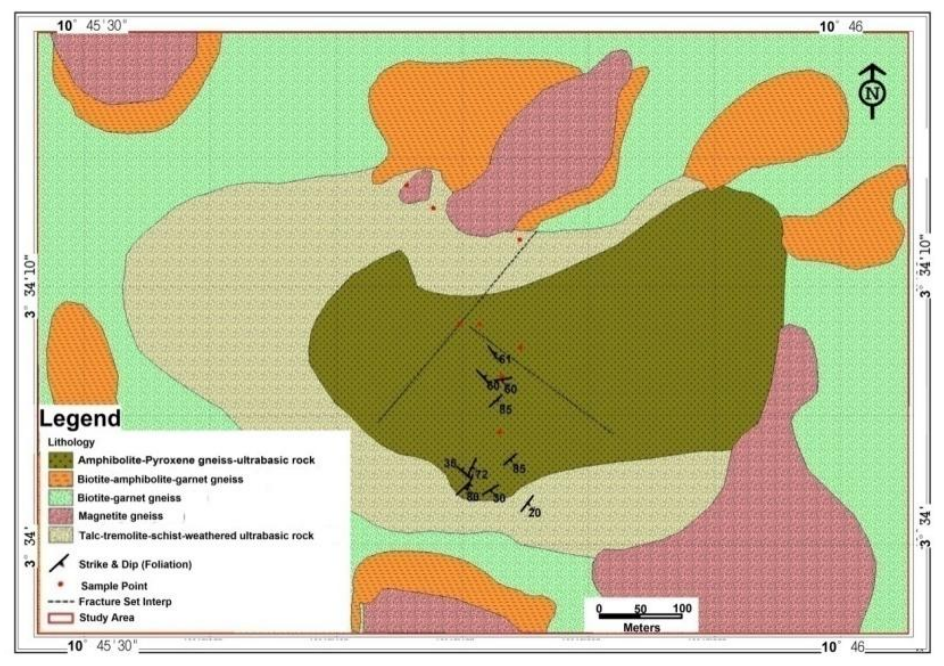

Figure2. Geological map of the study area showing the various lithologies intruded by the ultramafic rocks (after Ako et al., 2015) 
Geological Models of Platinum Group Elements (PGE) Depletion in Metamorphosed Ultramafic Rocks of the Nyong Series, Southeast Cameroon

\subsection{Geochemistry}

The Ni-Cu-Au- PGE data of the ultramafic rocks of the study area are presented in table 1. The ultramafic rocks of the northern limit of the Nyong Series show very low $\Sigma$ PGE contents with a very narrow range of $5-13 \mathrm{ppb}$ and $\Sigma \mathrm{Au}$-PGE concentrations from 7.7 to $521.7 \mathrm{ppb}$. Os, Rh and Ru were all below detection limits in the samples, thus only Pd, Pt and Ir were used for plotting and comparison in the study. Pd (3 to $5 \mathrm{ppb}$ ); $\operatorname{Ir}$ ( 2 to $7 \mathrm{ppb}$ ); $\mathrm{Pt}$ (3 to $8 \mathrm{ppb}$ ) and $\mathrm{Au}$ (1.3 to $3.9 \mathrm{ppb}$, except sample ESK 27 which has a concentration of $517.7 \mathrm{ppb}$ ) display relatively narrow variations. $\mathrm{Cu}$ content in the samples is relatively very low (0.69 to $11.2 \mathrm{ppm}$, except sample ESK 27 which again has a value of $50 \mathrm{ppm}$ ) while Ni contents range from 680-2622 ppm.

Table1. Ni-Cu-Au-PGE contents of the ultramafic rocks in the Nyong Series

\begin{tabular}{|c|c|c|c|c|c|c|c|c|c|c|c|c|c|c|c|}
\hline \multicolumn{2}{|c|}{ Sample No. } & \multirow[t]{2}{*}{ ESK 1} & \multirow[t]{2}{*}{ ESK2 } & \multirow[t]{2}{*}{ ESK 3} & \multirow[t]{2}{*}{$\begin{array}{c}\text { ESK } \\
4 \\
\end{array}$} & \multirow[t]{2}{*}{\begin{tabular}{|c|} 
ESK \\
5 \\
\end{tabular}} & \multirow[t]{2}{*}{ ESK6 } & \multirow[t]{2}{*}{$\begin{array}{c}\text { ESK } \\
7 \\
\end{array}$} & \multirow[t]{2}{*}{$\begin{array}{c}\text { ESK } \\
8\end{array}$} & \multirow[t]{2}{*}{$\begin{array}{c}\text { ESK } \\
9\end{array}$} & $\begin{array}{c}\text { ESK } \\
10 \\
\end{array}$ & \multirow[t]{2}{*}{$\begin{array}{c}\text { ESK } \\
11 \\
\end{array}$} & \multirow[t]{2}{*}{$\begin{array}{c}\text { ESK } \\
12 \\
\end{array}$} & \multirow[t]{2}{*}{$\begin{array}{c}\text { ESK } \\
13 \\
\end{array}$} & \multirow[t]{2}{*}{$\begin{array}{c}\text { ESK } \\
14 \\
\end{array}$} \\
\hline (ppb) & d.1 & & & & & & & & & & & & & & \\
\hline $\mathrm{Pt}$ & 3 & $<3$ & $<3$ & $<3$ & $<3$ & $<3$ & $<3$ & $<3$ & $<3$ & $<3$ & $<3$ & $<3$ & $<3$ & $<3$ & $<3$ \\
\hline $\mathrm{Pd}$ & 2 & 3.00 & 3.00 & 3.00 & 4.00 & 3.00 & 3.00 & 4.00 & 3.00 & 3.0 & 3.00 & 3.00 & 4.00 & 5.00 & \begin{tabular}{l|l}
5.00 \\
\end{tabular} \\
\hline $\mathrm{Rh}$ & 5 & $<5$ & $<5$ & $<5$ & $<5$ & $<5$ & $<5$ & $<5$ & $<5$ & $<5$ & $<5$ & $<5$ & $<5$ & $<5$ & $<5$ \\
\hline $\mathrm{Ir}$ & 1 & 4.00 & 4.00 & 7.00 & 4.00 & 4.00 & 5.00 & 4.00 & 7.00 & 2.0 & 4.00 & 2.00 & 2.00 & 2.00 & \begin{tabular}{l|l|}
3.00 \\
\end{tabular} \\
\hline Os & 10 & $<10$ & $<10$ & $<10$ & $<10$ & $<10$ & $<10$ & $<10$ & $<10$ & $<10$ & $<10$ & $<10$ & $<10$ & $<10$ & $<10$ \\
\hline $\mathrm{Ru}$ & 50 & $<50$ & $<50$ & $<50$ & $<50$ & $<50$ & $<50$ & $<50$ & $<50$ & $<50$ & $<50$ & $<50$ & $<50$ & $<50$ & $<50$ \\
\hline $\mathrm{Ni}(\mathrm{ppm})$ & 20 & 1461 & 1450 & 2235 & 2222 & 2133 & 2121 & 1593 & 1599 & 248 & \begin{tabular}{|l|l|}
9 & 2490 \\
\end{tabular} & \begin{tabular}{l|l}
0 & 2475 \\
\end{tabular} & 2479 & 2615 & \begin{tabular}{l|l}
5 & 2617
\end{tabular} \\
\hline $\mathrm{Cu}(\mathrm{ppm})$ & \begin{tabular}{|l|}
0.1 \\
\end{tabular} & 4.4 & 4.7 & 11.2 & 11 & 3.9 & 3.7 & 7.1 & 7.3 & 7.5 & 7.6 & 0.7 & 0.69 & 3.9 & 4.1 \\
\hline $\mathrm{Au}$ & 2 & 3.7 & 3.7 & 2.4 & 2.7 & 2.9 & 2.8 & 3.8 & 3 & 1.3 & 1.5 & 3.3 & 3.8 & 3.7 & 3.9 \\
\hline$\Sigma \mathrm{PGE}$ & - & 7 & 7 & 11 & 8 & 7 & 8 & 8 & 10 & 5 & 7 & 5 & 6 & 7 & 8 \\
\hline AU-PGE & - & 10.7 & 10.7 & 13.4 & 10.7 & 9.9 & 10.8 & 11.8 & 13 & 6.3 & 8.5 & 8.3 & 9.8 & 10.7 & 11.9 \\
\hline PPGE & - & 7 & 7 & 11 & 8 & 7 & 8 & 8 & 10 & 5 & 7 & 5 & 6 & 7 & 8 \\
\hline $\mathrm{Pd} / \mathrm{Ir}$ & - & 0.75 & 0.75 & 0.43 & 1 & 0.75 & 0.6 & 1 & 0.43 & 1.5 & 0.75 & 1.5 & 2 & 2.5 & 1.67 \\
\hline $\mathrm{Cu} / \mathrm{Ir}$ & - & 1.1 & 1.18 & 1.6 & 2.75 & 0.98 & 0.78 & 1.78 & 1.04 & 3.7 & 1.9 & 0.35 & 0.35 & 1.95 & 1.37 \\
\hline $\mathrm{Cu} / \mathrm{Pd}$ & - & 1.467 & 1.567 & 3.733 & 2.75 & 1.3 & \begin{tabular}{|l|l|}
1.233 \\
\end{tabular} & 1.775 & 2.433 & 2.5 & 2.53 & \begin{tabular}{|l|l|}
3 & 0.233 \\
\end{tabular} & \begin{tabular}{|l|l|}
3 & 0.173 \\
\end{tabular} & 0.74 & \begin{tabular}{l|l|}
+ & 0.82 \\
\end{tabular} \\
\hline $\mathrm{Pt}+\mathrm{Pd}+\mathrm{Au}$ & & 6.7 & 6.7 & 5.4 & 6.7 & 5.9 & 5.8 & 7.8 & 6.00 & 4.3 & 4.5 & 6.3 & 7.8 & 8.7 & 8.9 \\
\hline $\mathrm{Pt}+\mathrm{Pd}+\mathrm{Au} / \mathrm{C}$ & & 1.52 & 1.52 & 0.57 & 0.61 & 1.15 & 1.57 & 1.11 & 0.82 & $0.5^{\prime}$ & $0.5 \mathrm{C}$ & 9 & 11.3 & 2.23 & 2.17 \\
\hline $\mathrm{Pt}+\mathrm{Pd}+\mathrm{Au} / \mathrm{C}$ & $\mathrm{CaO}-$ & 134 & 134 & 270 & 670 & - & - & 390 & 200 & 4.58 & 4.89 & 42 & 48.75 & 870 & 890 \\
\hline \multicolumn{16}{|c|}{$\begin{array}{l}\text { d.l: detection limits } \\
\text { Table } 1 \text { (continued) }\end{array}$} \\
\hline Sample & & ESK & ESK & ESK & SK1 & ESK & ESK & ESK & ESK & & ESK & ESK & ESK & ESK & ESK \\
\hline No. & & 15 & 16 & 17 & 8 & 19 & 20 & 21 & 22 & & 23 & 24 & 25 & 26 & 27 \\
\hline (ppb) & d.1 & & & & & & & & & & & & & & \\
\hline $\mathrm{Pt}$ & 3 & $<3$ & $<3$ & $<3$ & $<3$ & $<3$ & $<3$ & $<3$ & $<3$ & & $<3$ & $<3$ & $<3$ & 8 & 4 \\
\hline $\mathrm{Pd}$ & 2 & 4.00 & 3.00 & 4.00 & 4.00 & 3.00 & 4.00 & 5.00 & 4.00 & & 4.00 & 4.00 & 5.00 & 5.00 & 4.00 \\
\hline $\mathrm{Rh}$ & 5 & $<5$ & $<5$ & $<5$ & $<5$ & $<5$ & $<5$ & $<5$ & $<5$ & & $<5$ & $<5$ & $<5$ & $<5$ & $<5$ \\
\hline $\mathrm{Ir}$ & 1 & 4.00 & 4.00 & 4.00 & 7.00 & 4.00 & 4.00 & 3.00 & 4.00 & & 4.00 & 2.00 & 2.00 & $<1$ & $<1$ \\
\hline Os & 10 & $<10$ & $<10$ & $<10$ & $<10$ & $<10$ & $<10$ & $<10$ & 10 & & $<10$ & $<10$ & $<10$ & $<10$ & $<10$ \\
\hline $\mathrm{Ru}$ & 50 & $<50$ & $<50$ & $<50$ & $<50$ & $<50$ & $<50$ & $<50$ & $<50$ & & $<50$ & $<50$ & $<50$ & $<50$ & $<50$ \\
\hline $\mathrm{Ni}(\mathrm{ppm})$ & 20 & 2009 & 2010 & 2188 & 2179 & 2110 & 2115 & 2610 & 262 & & 2506 & 2510 & 2456 & 2462 & 680 \\
\hline $\mathrm{Cu}(\mathrm{ppm})$ & 0.1 & 7.8 & 7.1 & 1.5 & 1.9 & 1 & 1.2 & 3 & 2.9 & & 8.4 & 8.2 & 3.1 & 3.3 & 50 \\
\hline $\mathrm{Au}$ & 2 & 3.2 & 3.3 & 1.6 & 1.5 & 2.1 & 2.1 & 2.5 & 2.8 & & 3.4 & 3.3 & 2.5 & 2.7 & 517.7 \\
\hline$\Sigma$ PGE & - & 8 & 7 & 8 & 11 & 7 & 8 & 8 & 8 & & 8 & 6 & 7 & 13 & 8 \\
\hline AU-PGE & - & 11.2 & 10.3 & 9.6 & 12.5 & 9.1 & 10.1 & 10.5 & 10.8 & & 11.4 & 9.3 & 9.5 & 14.7 & 525.7 \\
\hline PPGE & - & 8 & 7 & 8 & 11 & 7 & 8 & 8 & 8 & & 8 & 6 & 7 & 13 & 8 \\
\hline $\mathrm{Pd} / \mathrm{Ir}$ & - & 1 & 0.75 & 1 & 0.57 & 0.75 & 1 & 1.67 & 1 & & 1 & 2 & 2.5 & - & - \\
\hline $\mathrm{Cu} / \mathrm{Ir}$ & - & 1.95 & 1.78 & 0.38 & 0.27 & 0.25 & 0.3 & 1 & 0.73 & & 2.1 & 4.1 & 1.55 & - & - \\
\hline $\mathrm{Cu} / \mathrm{Pd}$ & - & 1.95 & 2.367 & 0.375 & 0.475 & 0.333 & 0.3 & 0.6 & 0.27 & & 2.1 & 2.05 & 0.62 & 0.66 & 12.5 \\
\hline $\mathrm{Pt}+\mathrm{Pd}+\mathrm{Au}$ & - & 7.2 & 6.3 & 5.6 & 5.5 & 5.1 & 6.1 & 7.5 & 6.8 & & 7.4 & 7.3 & 7.5 & 15.7 & 525.7 \\
\hline $\begin{array}{c}\mathrm{Pt}+\mathrm{Pd}+\mathrm{Au} \\
/ \mathrm{Cu}\end{array}$ & - & 0.92 & 0.89 & 3.73 & 5.91 & 5.1 & 5.17 & 2.5 & 2.35 & & 0.88 & 0.89 & 2.42 & 2.33 & \begin{tabular}{|l|}
10.43 \\
\end{tabular} \\
\hline $\begin{array}{c}\mathrm{Pt}+\mathrm{Pd}+\mathrm{Au} \\
/ \mathrm{CaO}\end{array}$ & - & 56.36 & 55 & 56 & 550 & - & - & 6.58 & 6.07 & & 12.13 & 12.37 & 107.14 & 85.56 & 100.91 \\
\hline
\end{tabular}

d.l: detection limits

$\mathrm{Pt}+\mathrm{Pd}+\mathrm{Au}$ values range from 4.3 to $15.7 \mathrm{ppb}$ (with the exception of sample 27 which show a value of $525.7 \mathrm{ppb}$ ) while $\mathrm{Cu} / \mathrm{Pd}$ ratios vary from 0.17 to 3.73 . Ni concentration is very high in the samples 
with a range of 680 to $2622 \mathrm{ppm}$ (Table 1). The average Pt/Pd ratio (1.4) of the ultramafic rock samples is less than that of the Merensky Reef (2.33). Also, the samples have average $\mathrm{Ni} / \mathrm{Cu}, \mathrm{Pd} / \mathrm{Ir}$ and $\mathrm{Pt} / \mathrm{Ir}$ ratios of 329.8, 1.01 and 0.06 , respectively. The Merensky Reef has average Pd/Ir and Pt/Ir ratios of 15.4 and 3.6 , respectively while those of the Platreef are 89.5 and 75.8 respectively ( Naldrett, 1989 ). Maier et al. (2008) suggested that the difference in Pt/Pd ratios between the Merensky Reef and the Platreef is either as a result of Pd loss from the Merensky sulfides due to mobilization in late-stage magmatic or hydrothermal melts and/or fluids or enhanced partitioning of $\mathrm{Pd}$ relative to $\mathrm{Pt}$ into the sulfide melt due to the Platreef magma having a higher oxygen fugacity than the Merensky magma.

\subsection{Models of PGE Depletion in Rocks Relevant to the Nyong Series}

The ultramafic rocks in the Nyong Series have very low PGE contents. Os, Rh and Ru are completely absent in the samples. These low PGE data suggest that the potential of these ultramafic rocks to produce exploitable PGE deposits is very low (Ako, 2016). However, there is also the possibility that the Nyong Series ultramafic intrusions are feeder intrusions with the implication that further PGE-rich sulphides were transported into wherever these feeder intrusions deposited them, either as lavas or possibly large-scale gabbro intrusions (e.g. Holwell et al., 2012). On the other hand as feeder intrusions, there may be further PGE deposits at depth and the mineralization in the studied ultramafic rock intrusions may simply represent a small fraction of a much large volume of sulphides. This will be related to having a larger body of magma at depth in which both PGE enrichment and sulphide saturation occurred. Huminicki et al., 2008 and Kozlu et al., 2014, have reported similar situations in which sulphide droplets in intrusion systems such as sills and dykes describe this style of mineralization above areas of PGE mineralization and sulphide saturation.

Generally, the concentration of PGE in magmas is influenced to a large extent by S saturation (Maier et al., 2008, Zhou et al., 2013 and Iheinfeld and Keays, 2011). However, it is important to seek explanations for the low levels of PGE in the Nyong samples in order to better enhance exploration in this region. Three main reasons are advanced and debated. The Nyong Series rocks have strong total PGE ( PGE) depletion and various mechanisms besides alteration (Ako et al., 2015) have been advanced to explain this observation including the fact that the parental magma might have been originally poor in PGE. The low PGE abundance may be attributed to melting of a depleted refractory lithospheric mantle source which had previously experienced periodic melt extraction as noted in the Voisey Bay mineralisation in Canada as depicted in model in Figure 3 (Lightfoot et al. 2012). Other models ascribe PGE depletion to sulphide segregation from magma at depths which reduced the $\Sigma$ PGE content or levels in the residual magma due to high $\mathrm{K}_{\mathrm{D}}\left(\sim 10^{4}\right)$ of PGE into these sulphides as illustrated in Figure 4 (e.g. Song et al., 2009a and b, Wang et al., 2011, Wei et al., 2013). The third scenario relates to PGE depletion due to metal retention in sulphide minerals in the mantle at low degrees of partial melting (Figure 5) (e.g. Keays, 1995). These scenarios can be evaluated for the ultramafics in the Nyong series of this study.

$\mathrm{Pt}$ and $\mathrm{Pd}$ are incompatible during mantle partial melting and previous melting will deplete the mantle source in Pt and Pd as suggested by Maier et al. (2012). Consequently, subsequent stage melts from a depleted refractory lithospheric mantle will produce PGE-depleted magma. However, previous studies of rocks of the Nyong Series have reported negative ENd values (Toteu et al., 1994a; Bayiga et al., 2011 and Ebah Abeng et al., 2012) (Figure 3) indicating the absence of a long-lived depleted mantle source. The fact that ENd values are negative show that the mantle has not been depleted of PGE so is a fertile mantle source and has the potential of generating PGE. If these valves were positive then it will show that it has a long-lived depleted source and the result would be a low Pd $+\mathrm{Pt}$ values in the primary ultramafic rocks. The higher the $\mathrm{ENd}$ values, the long-lived depleted mantle source and the lower the values of PGE and vice visa. The Nyong Rocks have negative ENd values meaning the mantle is fertile enough to generate PGE (Figure 3). Another reason should thus be accounted for their low PGE contents. It therefore suggests that the primary ultramafic intrusions here were derived largely from an asthenospheric mantle source with minor inputs from metasomatised lithospheric mantle. Therefore the mantle source of the Nyong Series should be fertile in $\Sigma$ PGE. 
Geological Models of Platinum Group Elements (PGE) Depletion in Metamorphosed Ultramafic Rocks of the Nyong Series, Southeast Cameroon

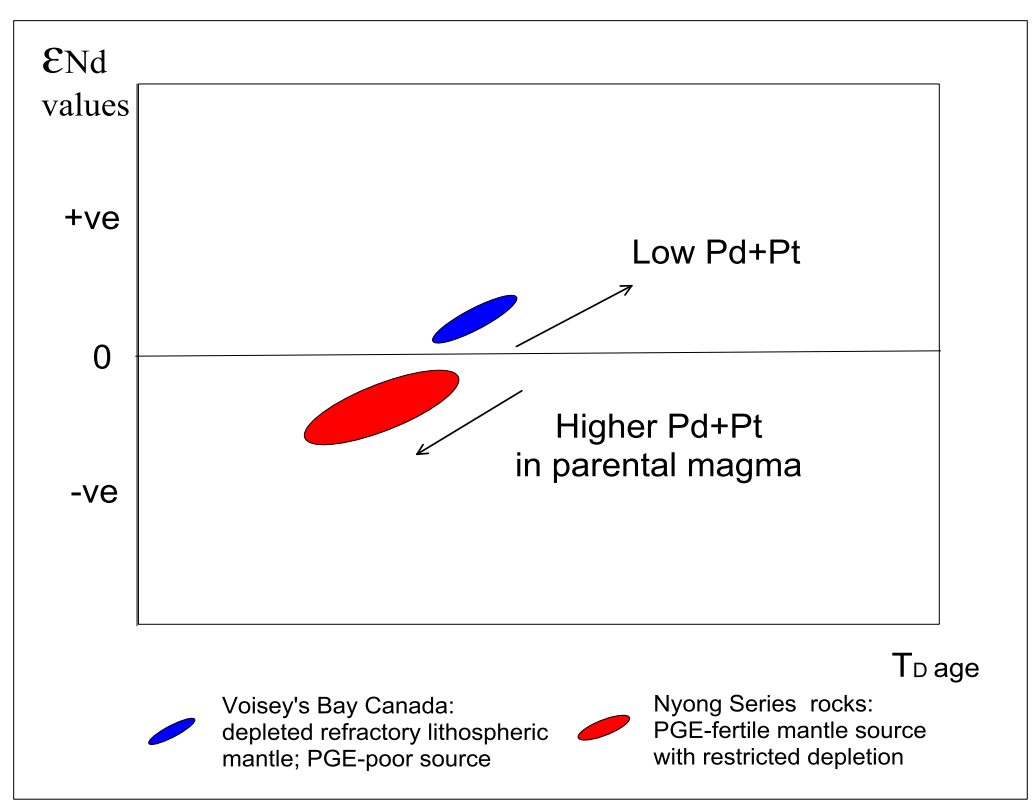

Figure3. Model depicting low $\sum P G E$ content in the Nyong Series rocks due to the nature of the mantle source

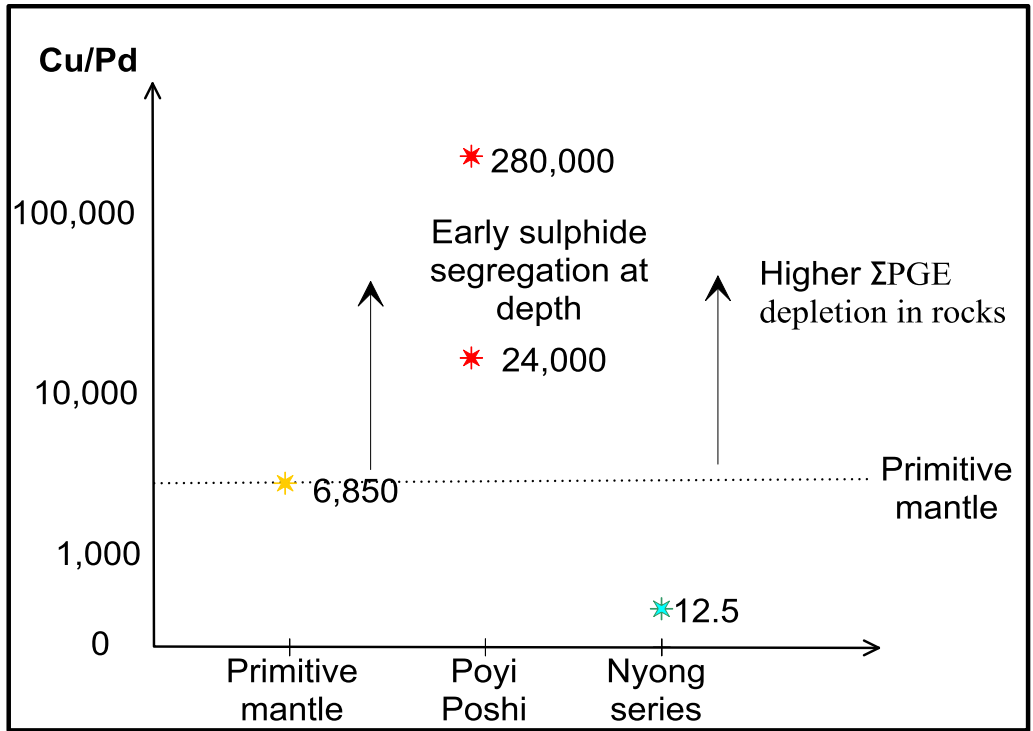

Figure4. Model illustrating low $\sum P G E$ content in the Nyong Series rocks due to early sulphide segregation at depth

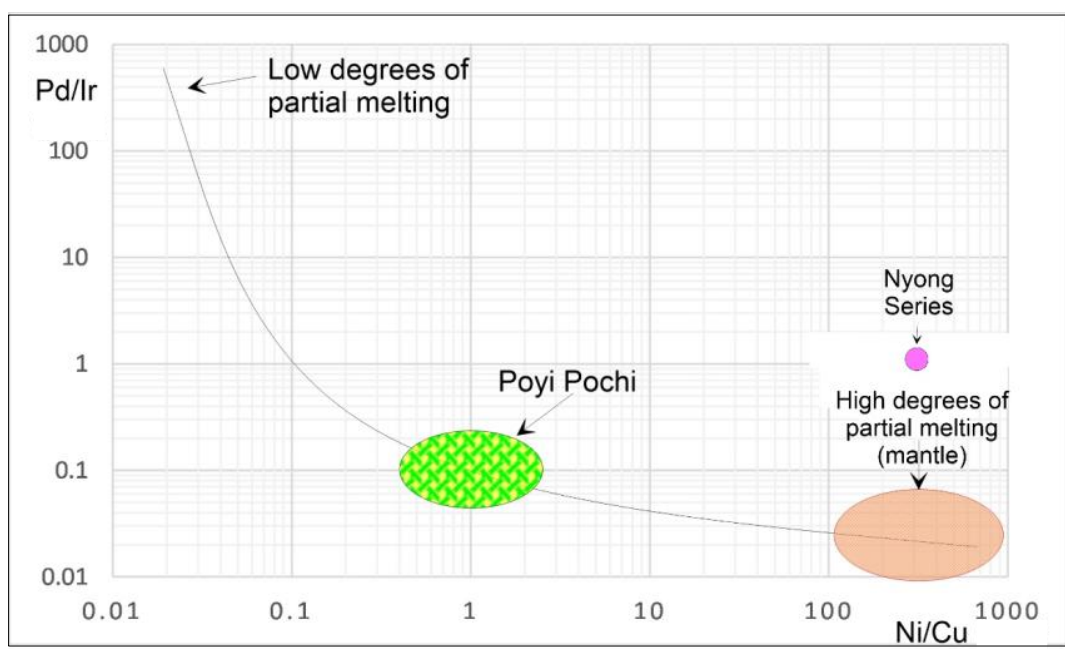

Figure5. Model showing low $\sum P G E$ content in the ultramafic rocks of the Nyong Series due to sulphide retention in mantle 
The $\mathrm{Cu} / \mathrm{Pd}$ ratios of the samples in this study range from 0.17 to 12.5 compared to the values of 24,000 to 280,000, (that are significantly higher than the primitive mantle values of 6850) of the Poyi Poshi ultramafics, Tarim, NW China (Yang et al. 2014). Early sulphide segregation will generally enhance $\mathrm{Cu} / \mathrm{Pd}$ ratios of the residual magma because $\mathrm{Pd}$ has much higher partition coefficient values between sulphide melts and silicate melts than $\mathrm{Cu}$ (Figure 4). Consequently, higher $\mathrm{Cu} / \mathrm{Pd}$ ratios imply parental magmas experienced early sulphide segregation, either in the mantle or during the evolution of magmas en route to the chamber where they crystallized. Unfortunately, primitive olivine is not preserved in the Nyong rocks as the forsterite of these olivines will allow for the evaluation of the primitive nature of these magmas. However, the geotectonic context of the Nyong series suggests that such magmas would have experienced limited fractionation before the emplacement. It is thus unlikely that the magma experienced early sulphide segregation in the deep crust.

Sulphide retention leading to poor PGE in ultramafics can also occur due to low degrees of partial melting (e.g. Lightfoot et al., 2012a). Os, Ir, Ru and Ni behave more compatible than Rh, Pt, Pd and $\mathrm{Cu}$ during partial melting of the upper mantle and therefore the $\mathrm{Pd} / \mathrm{Ir}$ ratio and $\mathrm{Ni} / \mathrm{Cu}$ ratios are sensitive to degrees of partial melting. Usually rocks from high degrees of partial melting have low $\mathrm{Ni}$ and Ir contents with low $\mathrm{Pd} / \mathrm{Ir}$ and high $\mathrm{Ni} / \mathrm{Cu}$ ratios(Maier et al., 2008 ) whereas basaltic lavas from low degrees of partial melting usually have low $\mathrm{Ni}$ and Ir contents, with high $\mathrm{Pd} / \mathrm{Ir}$ and low $\mathrm{Ni} / \mathrm{Cu}$ ratios (e.g. Barnes and Maier, 1999).

$\mathrm{Pd} / \mathrm{Ir}$ ratios of $10-24$ and $\mathrm{Ni} / \mathrm{Cu}$ ratios of 0.9 to 1.6 plot in the field of high $\mathrm{Mg}$ basaltic rocks indicating a low to moderate degree of partial melting. Keays (1995) estimated that about $\sim 25 \%$ is the minimum degree of melting in the mantle (according to $\mathrm{Pd} / \mathrm{Ir}$ and $\mathrm{Ni} / \mathrm{Cu}$ ratios of $\sim 01$ and $\sim>10$, respectively) capable of extracting all the sulphides in the mantle. The Pd/Ir ratio in this study reaches a height of 2.5 and this suggests that sulphide retention in the mantle or at depth seems to be the most likely reason to account for the PGE depletion of the rocks of the Nyong series (Figure 5).

The segregation of sulphides and PGEs from silicate melts is perhaps the most important aspect of $\mathrm{Cu}-\mathrm{Ni}$-PGE mineralization, on which several views have been proposed (Barnes et al., 2004). The altered pyroxenites and amphibolites in the northeastern corner of the Nyong Series reveal that coarsegrained olivine and pyroxenes are the dominating minerals in these ultramafics rocks where the matrices of intergranular spaces of the cumulates are occupied by medium-to-fine grained, magnetite and sulphides which could be pyrrhotite and pentlandite which have been altered to pyrite (Ako et al., 2015). The olivine and pyroxenes have been altered to fine grained secondary hydrous silicates such as actinolite, tremolite and chlorite. The presence of these secondary hydrous silicates suggests that if PGE mineralization is present, they are product of dissolution and redeposition during hydrothermal alteration. The change in texture from coarse-grained to fine-grained, and appearance of diverse mineralogy (silicates, sulphides and oxides) subsequent to the olivine crystallization/fractionation, is an important event in the ultramafic rocks in the Nyong Series that could have provided a congenial environment for sulphur saturation conditions in the magma. The behavior of PGE availability in ultramafic rocks and magmatic volatile phases are studied to identify the geochemical controls of the manner they are formed and distributed in the Earth's crust, and to understand the primary mantlederived magmatic processes (Balaram et al., 2013). The olivine, pyroxene, magnetite and sulphides of $\mathrm{Ni}, \mathrm{Fe}$ and $\mathrm{Cu}$ are the most compatible mineral phases for PGE enrichment in the ultramafic rocks (Keays et al., 1981, Crocket, 2002), and are mainly important and responsible for PGE enrichment in magmatic systems. There are five important factors that have been advocated by some authors (e.g. Holwell and McDonald, 2006; Maier, 2005) for PGE deposits in many ultramafic and associated mafic rocks. These factors include, (i) degree of partial melting of PGE-enriched/fertile mantle, (ii) metasomatism and fractionation of PGE-rich magma, (iii) dissolved sulphur (S), (iv) S-saturation condition during crystallization of magma, and (v) hydrothermal intrusive. These factors may operate together or separately depending on the prevailing geological conditions during their emplacement and formation (Naldrett, 2010). That notwithstanding, the magmatic enrichment of PGEs in ultramafic rocks is primary controlled by the degree of partial melting of the juvenile mantle from which the mafic magma is derived. In general, the generation of mafic and ultramafic magmas typically takes place in the asthenospheric or lithospheric mantle, but contributions of partial or wholesale melts from the crust can also modify the composition of these mantle-derived magmas. The concentration of $\mathrm{Ni}$, $\mathrm{Cu}$, and PGEs in crustal and even in mantle rocks is very low when compared to bulk earth (Barnes 
and Lightfoot, 2005) because these elements are siderophile (i.e., they prefer to form metals rather than oxides) and thus were concentrated in the core during the early history of the earth.

High $\mathrm{MgO}, \mathrm{Fe}_{2} \mathrm{O}_{3}$ t, Ni and low $\mathrm{CaO}, \mathrm{Na}_{2} \mathrm{O}, \mathrm{Al}_{2} \mathrm{O}_{3}, \mathrm{~K}_{2} \mathrm{O}$, TiO, PGEs and $\mathrm{V}$ in the ultramafic rocks in the Nyong Series suggest high degree of partial melting from a depleted mantle source that existed during the development of the peridotite magma (Ako, 2016). The observation about the origin of ultramafic magma and the various mechanisms for the fertility of juvenile mantle (Sproule et al., 2002), and dissemination of sulphide within the ultramafic complex have been proposed from several areas (Barnes et al., 2004; Lesher and Barnes, 2009) showing similar geochemical trend for the ultramafic rocks of the Nyong Series. The low $\mathrm{Pd} / \mathrm{Ir}, \mathrm{Cu} / \mathrm{Pd}, \mathrm{Pt}+\mathrm{Pd}+\mathrm{Au}, \mathrm{Cu} / \mathrm{Ir}, \mathrm{Cu} / \mathrm{Pd}, \mathrm{Pt}+\mathrm{Pd}$ $+\mathrm{Au} / \mathrm{Cu}$ and $\mathrm{Pt}+\mathrm{Pd}+\mathrm{Au} / \mathrm{CaO}$ ratios in the rocks (Table 1), and low concentration of both PPGE and IPGE (Table 1) from the study area compared to similar studies in other parts of the world indicate that the ultramafic rocks of the Paleoproterozoic Nyong Series were formed during S-undersaturated condition (Chen and Xia, 2008; Balaram et al., 2013). The averages of these ratios indicate that the PGEs and Au could behave differently in the same samples. Despite the high $\mathrm{MgO}$, very low PGEs in these rocks suggest that the magma is derived from PGE-poor/depleted mantle (Ako, 2016). It has been suggested that the IPGEs are refractory and tend to be retained in the mantle peridotites during partial melting (Brain, 2011; Evans et al. 2012; Barnes et al., 2011). The low PGE contents in the rocks could be due to sequestration during the magma process (Bockrath et al., 2004) or to extremely very limited hydrothermal mobility (Barnes and Lui, 2012). The low PGE contents might also be caused by an increase in oxygen fugacity (Fonseca et al., 2009). There is a slight positive correlation between Pt and Pd which suggests that Pt is usually associated with Pd (Barnes and Lui, 2012; Godel et al., 2007). Barnes et al. (2012) reported that PGE depletion in the silicate melt of the Mount Keith nickel deposit, Yilgarn Craton, Australia, due to sulphide liquid extraction is limited by entrainment of sulphide liquid droplets and continuous equilibrium with the transported silicate magma. Keays $e t$ al. (2012) also investigated PGE in ultramafic series of the Stillwater Complex, Montana and reported that the rocks contain the highest $\mathrm{MgO}$ and lowest $\mathrm{Al}_{2} \mathrm{O}_{3}$ contents, as all the $\mathrm{Al}_{2} \mathrm{O}_{3}$ in the peridotites would have been contributed by interstitial magma. These rocks thus have a very low trapped silicate melt component. The small amount of $\mathrm{Pd}$ and $\mathrm{Pt}$ in the low $\mathrm{Al}_{2} \mathrm{O}_{3}$ rocks was probably contributed by tiny amounts of cumulus sulphides. Generally, the ultramafic rocks of the Nyong Series have very low PGE-Au contents(except samples ESK 26 and 27)(Table 1) which is similar to what Maier and Barnes (1999a) reported in the ultramafic rocks of the Curaca Valley of Bahia in the NE corner of the Transamazonian belt in Brazil and in other parts of the world. Hugh (1993) reported that in rocks such as ocean-floor basalts PGEs concentrations are so low that some elements are below the limit of detection. This might have been the situation with the Nyong Series ultramafic rocks as their Os, Rh and $\mathrm{Ru}$ are below detection limits and are suggested to have formed in the ocean ridge and floor environment (Table 1). In such cases analysis may be limited to the elements $\mathrm{Au}, \mathrm{Pd}$, and Ir. The PGE geochemistry can also be used to understand the mechanism responsible for the $\mathrm{Ni}-\mathrm{Cu}$ and PGE deposits in different geological and tectonic settings (Li and Ripley 2009; Naldrett, 2010; Balaram et al., 2013).

The recognition of rocks with strong PGE depletion signatures at the Nyong Series in the context of the depletion signatures recognized at Sudbury, Noril'sk and the Vosiey's Bay (Keays and Lightfoot, 2004; Lightfoot and Keays, 2005 and Lightfoot et al., 2012) provides further support to the suggestion that the mineralizing process produces not only the signature of anomalous to economic metal enrichment but also measurable metal depletion signature in different silicate melts. Whether the ultramafic intrusions in the Nyong Series are anomalous with respect to the Sudbury, Noril'sk and Vosiey's Bay intrusions, in so far as the parental magma had anomalously low PGE abundance levels is a key question. Modeling of the PGE content in the ultramafic intrusions in the Nyong Series indicates their parental magmas had the same low PGE contents as the Sudbury, Noril'sk and Vosiey's Bay magmas. It would be an unusual coincidence if these similar features of low PGE concentrations were resulted from different processes.

\section{CONCLUSION}

Ultramafics in the Nyong Series are altered and metamorphosed resulting in low PGE concentration and despite their high $\mathrm{MgO}$ and $\mathrm{Ni}$ contents, low PGE contents suggest that the magma is derived from PGE-poor/depleted mantle. Low $\mathrm{Cu}$-Au-PGE content in the rocks suggests melt produced in an 
oceanic ridge setting capable of forming major Ni sulphide deposits. Natures of the mantle source, sulphide segregation at depth and sulphide retention in the mantle are models proposed for depletion of PGE relevant to the rocks of Nyong Series.

\section{ACKNOWLEDGEMENT}

This article is part of the PhD thesis of the first author supervised by Prof. C. E. Suh (CES) at the University of Buea, Cameroon and completed within the research framework of economic geology on the Precambrian Mineral belt of Cameroon supported by University of Buea, Faculty Grants to CES. We gratefully acknowledge funding from the AvH Stiftung, Germany (courtesy of CES) and the Research grant in support of this thesis from the national body of Academic Staff Union of Universities (ASUU, Nigeria).

\section{REFERENCES}

[1] Ako, T. A. (2016). Petrochemistry of Metamorphosed Ultramafic Rocks in the Paleoproterozoic Nyong Series (SE Cameroon) and their bearing on Platinum-Group Elements (PGES) Mineralisation. PhD thesis, University of Buea, Cameroon,180Pp.

[2] Ako, T. A., Vishiti, A., Ateh, K. I., Kedia, A. C. and Suh, C. E. (2015). Mineral Alteration and Chlorite Geothermometry in Platinum Group Element (PGE)-bearing meta-ultramafic rocks from South East Cameroon. Journal of Geosciences and Geomatics, 3 (4): 96-108.

[3] Balaram, V., Singh, S. P., Satyanarayanan, M. and Anjaiah, K. V. (2013). Platinum group elements geochemistry of ultramafic and associated rocks from Pindar in Madarawa Igneous Complex, Bundlkhand massif, Central India. Journal of Earth System Sciences, 122 (1): 79-91.

[4] Barnes, S. J., Fiorentini, M. L. and Fardon, M. C. (2012). Platinum group element and nickel sulphide ore tenors of the Mount Keith nickel deposit, Yilgarn Craton, Australia. Mineralium Deposita, 47: 129-150.

[5] Barnes, S-J. and Lightfoot, P.C. (2005). Formation of magmatic nickel-sulfide ore deposits and processses affecting their copper and platinum-group element contents. In Hedenquist, J. W., Thompson, J.F.H., Goldfarb, R.J. and Richards, J.P. (eds.) Economic Geology $100^{\text {th }}$ Anniversary Volume, 179-213.

[6] Barnes, S-J. and Lui, W. (2012). Platinum and palladium mobility in hydrothermal fluids: evidence from komatiites and from thermodynamic modeling. Ore Geology Reviews, 44, 49-58.

[7] Barnes, S-J. and and Maier, W.D. (1999). The fractionation of $\mathrm{Ni}, \mathrm{Cu}$, and the noble metals in silicate and sulphide liquids. Geological Association of Canada Short Course Notes, 13: 69-106.

[8] Barnes, S-J., Godel, B. M., Locmelis, M., Fiorinitini, M. L. and Ryan, C. G. (2011). Extremely Ni-rich FeNi sulfide assemblages in Komatiitic dunite at Betheno, Western Australia: results from synchrotron X-ray fluorescence mapping. Austrialian Journal of Earth Sciences, 58 (7): 691-709.

[9] Barnes, S-J., Hill, R. E. T., Perring, C. S. and Dowling, S. E. (2004). Lithospherical exploration for Komatiite-associated Ni-sulfide deposits: Stratigies and limitations. Contributions to Mineralogy and Petrology, 82: 259-293

[10] Bayiga, E. C., Bitom, D., Ndjigui, P.-D. and Bilong, P. (2011). Mineralogical and geochemical characterization of weathering products of amphibolites at SW Eséka (Northern border of the Nyong unit, SW Cameroon). Journal of Geology and Mining Research,3 (10): 281-293.

[11] Bessoles, B. and Tromprtte, R. (1980). Géologie de l'Afrique: la chaîne Panafrique "zone mobile d'Afrique Centrale (partie sud) et zone Soudanaise" Mém. B.R.G.M, 92: 396p.

[12] Bockrath, C., Ballhaus, C. and Holzheid, A. (2004). Fractionation of the platinum-group elements during mantle melting. Science, 305: 1951-1953.

[13] Brain, D. G. (2011). Igneous Petrology of the Ni-Cu-PGE Mineralised Tamrack Intrusion, Aitkin and Carlton Counties, Minnesota. MSc thesis of University of Minnesota (156).

[14] Chen, G. and Xia, B. (2008). Platinum-group elemental geochemistry of mafic and ultramafic rocks from the Xigaze ophiolite, Southern Tibet. Journal of Asian Earth Sciences, 32: 406-422.

[15] Crocket, J. H. (2002). Platinum-group elements in basalts from Maui, Hawai'i: low abundances in alkali basalts: Canadian Mineralogist, 40: 585-610

[16] Ebah Abeng, A. S., Ndjigui, P-D., Beyanu, A. A., Tessontsap, T. and Bilong, P. (2012). Geochemistry of pyroxenites, amphibolites and their weathered products in the Nyong unit, SW Cameroon (NW border of Congo Craton): Implications for Au-PGE exploration. Journal of Geochemical Exploration, 114: 1 - 19.

[17] Evans, D. M., Barrett, F. M., Prichard, H. M. and Fisher, P. C. (2012). Platinum-Palladium gold mineralization in the Nkenja Mafic-Ultramafic body, Ubendian Metamorphic belt, Tanzania. Mineralium Deposita, 47: 175-196. 
[18] Feybesse, J. L., Johan, V., Maurizot, P. and Abessol, A. (1986). Evolution tectono-métamorphique libérenne et éburnéenne á la partie NW du craton zaïrọis (SW Cameroon). Current Research In Africa Journal of Earth Sciences, Matheis and Schandelmeier (eds) Balkema, Rotterdam: 9 - 12.

[19] Fonseca, R. O. C., Campbell, I. H., O’Neil, H. S. C. and Allen, C. M. (2009). Solubility of Pt in sulfide mattes: Implications for the genesis of PGE-rich horizons in layered intrusions. Geochimica et Cosmochimica Acta, 73: 5768-5777.

[20] Holwell, D. A. and McDonald, I. (2006). Petrology, geochemistry and the mechanisms determining the distribution of platinum-group element and base metal sulphide mineralization in the Platreef at Overysel, nortern Bushveld Complex, South Africa. Mineralium Deposita, 41(6): 575-598.

[21] Holwell, D. A. and McDonald, I. (2010). A review of the behavior of platinum group elements within natural magmatic sulfide ore systems. Platinum Metals Review, 54(1): 26-36.

[22] Holwell, D. A., Abraham-James, T., Keays, R. R. and Boyce, A. J. (2012). The nature and genesis of marginal $\mathrm{Cu}-\mathrm{PGE}-\mathrm{Au}$ sulphide mineralization in Paleogene Macrodykes of the Kangerlussuaq region, East Greenland. Mineralium Deposita, 47: 3-21.

[23] Hugh R. R. (1993). Using geochemical data: Evaluation, Presentation and Interpretation. Pearson Education Limited, Edinburgh Gate (380).

[24] Huminiki, M. A. E., Sylvester, P. J. Lastra, R, Cabri, L. J., Evans-Lamswood, D. and Wilton, D. H. C. ( 2008). First report of platinum-group minerals from a hornblende gabbro dyke in the vicinity of Southeast Extension Zone of the Voisey's Bay Ni-Cu-Co deposit, Labrador. Contribution toMineralogy and Petrology, 92: 129-164.

[25] Ihlenfeld, C. and Keays, R. R. (2011). Crustal contamination and PGE mineralization in the Platreef, Bushveld Complex, South Africa: evidence for multiple contamination events and transport of magmatic sulfides. Mineraliun Deposita, 46:813-832

[26] Keays, R. R., Lightfoot, P. C. and Hamlyn, P. R. (2012). Sulfide saturation history of the Stillwater Complex, Montana: chemostratgraphic variation in Platinum group elements. Mineralium Deposita, 47:151-173.

[27] Keays, R. R. (1995). The role of komatiite and picritic magmatism and S-saturation in the formation of ore deposits, Lithos, 34: 1-18.

[28] Keays, R. R., Ross, J. R. and Woolrich, P. (1981). Precious metals in volcanic peridotites associated nickel sulfide deposits in Western Australia. II: Distribution within the ores and host rocks at Kambalda. Economic Geology, 76: 1645-1674.

[29] Kozlu, H., Prichard, H. M., Melcher, F., Fisher, P.C., Brough, C. P. and Stueben, D. (2014). Platinum group element (PGE) mineralisation and chromite geochemistry in the Berit ophiolite (Elbistan/Kahramanmaraş), SE Turkey. Ore Geology Reviews, 60:97-111.

[30] Lasserre, M. and Soba, D. (1976). Age libérien de granodiorites et des gneiss à pyroxene du Cameroon méridional. Bullutin, B.R.G.M. 2è série, section IV (I): 17 - 32.

[31] Ledru, P., Johan, V., Milési, J. P. and Tegyey, M. (1994). Makers of the last stages of the Palaeoproterozoic collision: evidence for a 2 Ga continent involving circum- South Atlantic Provinces. Precambrian Research, 68: 169-191).

[32] Lerouge, C., Cocherie, A., Toteu, S. F., Penaye, J., Mile'si. J., Tchameni. R., Nsifa, E. N. Fanning, C. M. and Deloule, E. (2006). Shrimp U-Pb Zircon age for Paleoproterozoic sedimentation and 2.05Ga syntectonic plutonism in the Nyong Group, South-Western Cameroon: consequences for the Eburnean Transamazonian belt of NE Brazil and Central Africa. Journal of African Earth Sciences, 44(4/5): 413427.

[33] Lesher, C. M. and Barnes, S-J. (2009). Komatiite-associated Ni-Cu-(PGE) Deposits; In: Magmatic NiCuPGE deposits: Genetic models and exploration, edited by Li, C. and Ripley, E. M. Geological Publishing House of China, Beijing, 27-101.

[34] Li, C. and Ripley, E. M. (2009). Sulfur contents at sulfide-liquid or anhydrite saturation in silicate melts: empirical equations and example applications. Economic Geology, 104: 405 - 412.

[35] Lightfoot, P. C. and Keays, R. R. (2005). Siderophile and chalcophile metal variations in flood basalts from the Siberian trap, Noril'sk region: Implication for the origin of the Ni-Cu-PGE sulfide ores. Economic Geology, 100: 439-462.

[36] Lightfoot, P. C., Keays, R. R., Evans-Lambswood, D. and Wheeler, R. (2012). S-saturation history of Nain Plutonic Suite mafic intrusions: origin of the Voisey's Bay deposit, Labrador, Canada. Mineralium Deposita, 47: 23-50.

[37] Maier, W. D. (2005). Platinum-group element deposits and occurrences: Mineralisation styles, genetic concepts and exploration criteria. Journal African Earth Sciences, 41: 165-191. 
[38] Maier, W. D. and Barnes, S-J. (1999a). Platinum- group elements in silicate rocks of the lower, critical, and main zones at Union Section,Western Bushveld Complex. Journal of petrology, 40: 1647-1617.

[39] Maier, W. D. and Barnes, S-J. (1999b). The origin of Cu sulphide deposits in the Curaçá valley, Bahia, Brazil; evidence from $\mathrm{Cu}, \mathrm{Ni}$, Se and platinum-group elements concentrations. Bulletin of Society ofEconomic Geology, 94: 165-183.

[40] Maier, W. D., Peltonen, P., McDonald, I., Barnes, S. J., Barnes, S-J., Hatton, C. and Viljoen, F. (2012). The concentration of platinum-group elements and gold in southern African and Karelian kimberlitehosted mantle xenoliths: implications for noble metal content of the Earth's mantle. Chemical Geology, 302-303: 119-135.

[41] Naldrett, A. J. (1989). Magmatic sulfide deposits. Oxford University Press Monographs on Geology and Geophysics, 14 (186).

[42] Naldrett, A. J. (2010). Secular Variation of Magmatic Sulfide Deposits and their Source Magmas. Economic Geology, 105: 669 - 688.

[43] Owona, S., Mvondo, J. O., Ekodeck, G. E. (2013). Evidence of quartz, feldspar and amphibole crystal plastic deformation in the Paleoproterozoic Nyong complex shear zones under amphibolites to granulite conditions (West Central African Fold Belt, SW Cameroon). Journal of Geography and Geology, 5(3):186-201.

[44] Owona, S., Schulz, B., Ratschbacher, L., Ondoa, J. M., Ekodeck, G. E., Tchoua, F. M. and Affaton, P. (2011). Pan-African Metamorphism evolution in the southern Yoaunde Group (Qubannguide Complex, Cameroon) as revealed by EMP-Monazite dating and thermobarometry of garnet metapelites. Journal of African Earth Sciences, 59: 125-139.

[45] Pénaye, J., Toteu, S. F., Tchameni, R., Van Schmus, W. R., Tchakounté, J., Ganwa, A., Minyem, D. and Nsifa, E. N. (2004). The 2.1 Ga West Central African Belt in Cameroon: extension and evolution. Journal of African Earth Sciences, 39: 159-164.

[46] Polinares Consortium (2012). Fact Sheet: Platinum Group Metals. Polinnares working paper no. 35: 1-16.

[47] Qing, L. Quanlin, H. Liewen, X. Hui, L. Shanqin, N. and Yudong, W. (2012). Different Origins of the Fractionation of Platinum-Group Elements in Raobazhai and Bixi Ling Mafic Rocks from Dabie Orogen, Central China. Journal of Geological Research, (2012): 1-11.

[48] Randine, K., Kumar, J. V. and Korakoppa, M. (2015). Platinum-group elements mineralization in the cumulate gabrro of Phenai Mata Complex, Deccan Large Igneous Province, India. Current Science, 108 (10): 1796 - 1798.

[49] Savard, D., Barnes, S. J. and Meisel, T. (2010). Comparison between Nickel-Sulfur Fire Assay Te CoPrecipitation and isotope Dilution with High-Pressure Asher acid digestion for the determination of platinum-group elements, rhenium and gold. Geo-Standards and Geoanalytical Research, 34 (34): 281291.

[50] Shang, C. K., Liégois, J-P., Satir, M. and Nsifa, E. N. (2010). Late Archaean high-K granite geochronology of the northern metacratonic margin of the Archaean Congo Craton, Southrn Cameroon: Evidence for Pb-loss due to non-metamorphic causes. Gondwana Research, 18: 337-355.

[51] Song, X. Y., Keays, R. R., Zhou, M. F., Qi, L., IhIenfeld, C. and Xiao, J. F. (2009a) Siderophile and chalcophile elemental constraints on the origin of the Jinchuan $\mathrm{Ni}-\mathrm{Cu}-(\mathrm{PGE})$ sulfide deposit, NW China. Geochimica et Cosmochimica Acta, 73: 404-424

[52] Song, X. Y., Keays, R. R., Xiao, L., Qi, H. W. and Ihlenfeld, C, (2009b). Platinum-group element geochemistry of the continental flood basalts in the central Emeishan Large Igneous Province, SW China. Chemical Geology, 262: 246 - 261

[53] Sproule, R. A., Lesser, C. M., Ayer, J. A. and Thurston, P. C. (2002). Komatiites and komatiitic basalts of the Abititi greenstone belt: A proposed model for their formation. Precambrian Research, 115: 153-186.

[54] Toteu, F. S., Van Schmus, W. R., Penaye, J. and Nyobé, J. B. (1994b).U-Pb and Sm-Nd evidence for Eburnean and Pan-African high grade metamorphism in cratonic rocks of Southern Cameroon. Precambrian Research, 67: 321-347.

[55] Toteu, S. F., Pénaye, J., Van Schmus, W. R. and Michard, A. (1994a). Preliminary U-PB and Sm-Nd geochronologic data on the North Central Cameroon: Contribution of the Archaean and Paleoproterozoic crust to the edification of an active domain of the Pan-African orogeny. Canadian Research of Acadamic Sciences, Paris, 319(Series II): 1519 - 1524.

[56] Wang, Y. W., Wang, J. B., Wang, L. J., Long, L. L., Liao, Z., Zhang, H.Q. and Tang, P. Z. (2011). Problems of PGE metallogenesis related to mafic-ultramafic complexes in North Xinjiang, China. Geoscience Frontiers, 2: 187-198. 
[57] Wei, B., Wang, C. Y., Li, C. S. and Sun, Y. L. (2013). Origin of PGE-depleted Ni-Cu sulfide mineralistion in the Triassic Hongqiling 7 orthopyroxenite intrusion, Central Asian Orogenic Belt, Northern China. Economic Geology, 108: 1813-1831.

[58] Yang, S. H., Zhou, M. F., Lightfoot, P. C., Xu, J. F., Wang, C. Y., Jang, C.Y. and Qu, W. J. (2014). Re-Os isotope and platinum-group element geochemistry of the Pobei Ni-Cu sulfide-bearing mafic-ultramafic complex in the northern part of the Tarim craton. Mineralium Deposita, 49 (3): 381-397.

[59] Zhou, M. F., Chen, W. T., Wang, C. Y., Prevec, S. A., Liu, P. P., Howarth, G. H., 2013. Two stages of immiscible liquid separation in the formation of Panzhihua-type Fe-Ti-V oxide deposits, SW China. Geoscience Frontiers, 4: 481-502.

Citation: T. A. Ako et al. (2017). Geological Models of Platinum Group Elements (PGE) Depletion in Metamorphosed Ultramafic Rocks of the Nyong Series, Southeast Cameroon, International Journal of Mining Science (IJMS), 3(4), pp.52-63, DOI: http://dx.doi.org/ 10.20431/2454-9460.0304005.

Copyright: (C) 2017 T. A. Ako. This is an open-access article distributed under the terms of the Creative Commons Attribution License, which permits unrestricted use, distribution, and reproduction in any medium, provided the original author and source are credited 